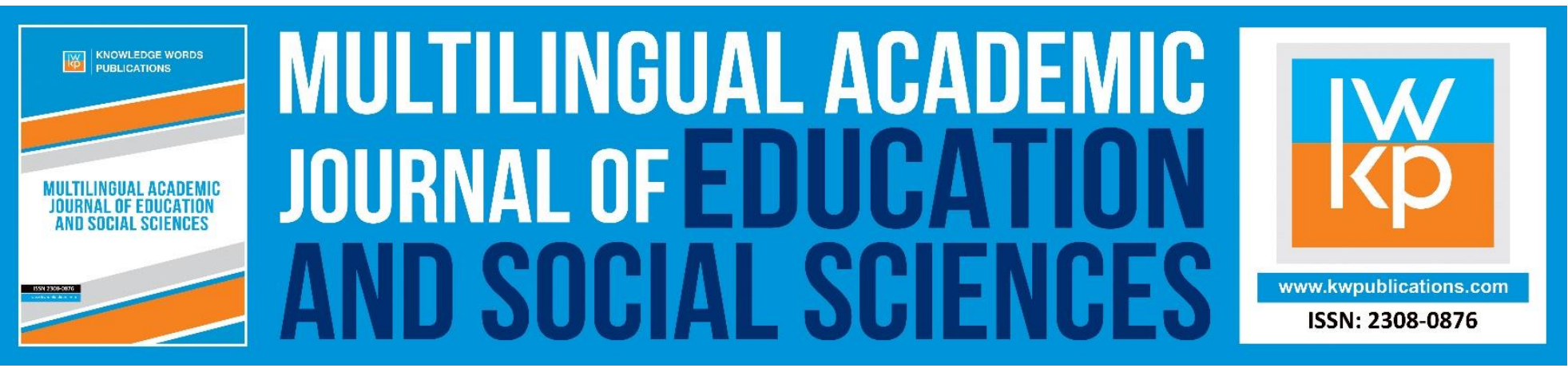

\title{
Personality Factors as Predictors of Social Capital
}

\author{
S. Lakshmi, R. Lakshmi \& R B N Sinha
}

To Link this Article: http://dx.doi.org/10.46886/MAJESS/v5-i1/2428

DOI: 10.46886/MAJESS/v5-i1/2428

Received: 22 June 2017, Revised: 21 July 2017, Accepted: 08 September 2017

Published Online: 25 October 2017

In-Text Citation: (Lakshmi et al., 2017)

To Cite this Article: Lakshmi, S., Lakshmi, R., \& Sinha, R. B. N. (2017). Personality Factors as Predictors of Social Capital. Multilingual Academic Journal of Education and Social Sciences, 5(1), 44-56.

Copyright: (C) The Authors 2017

Published by Knowledge Words Publications (www.kwpublications.com)

This article is published under the Creative Commons Attribution (CC BY 4.0) license. Anyone may reproduce, distribute, translate and create derivative works of this article (for both commercial and non-commercial purposes), subject to full attribution to the original publication and authors. The full terms of this license may be seen

at: http://creativecommons.org/licences/by/4.0/legalcode

Vol. 5, No. 1, 2017, Pg. 44 - 56

https://kwpublications.com/journals/journaldetail/MAJESS

JOURNAL HOMEPAGE

Full Terms \& Conditions of access and use can be found at https://kwpublications.com/pages/detail/publication-ethics 


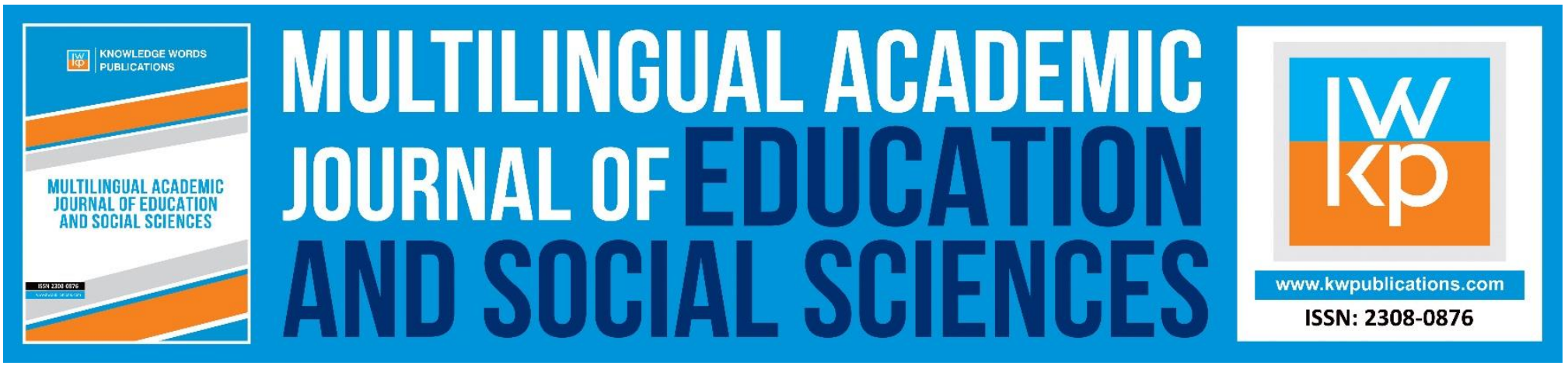

\title{
Personality Factors as Predictors of Social Capital
}

\author{
S. Lakshmi, R. Lakshmi \& R B N Sinha \\ Research scholar, PG Dept. of Psychology, BRA Bihar University, Muzaffarpur, Associate \\ Professor, Dept. of Psychology, RN College, Hajipur, Professor of Psychology \& Coordinator of \\ MBA, BS College, Danapur, Patna 800012. \\ Email: lakshmi.swarupa1203@gmail.com,rupalakshmi29@gmail.com, \\ rbns2@rediffmail.com
}

\begin{abstract}
Two hundred students as respondents randomly selected from semi-urban based degree colleges of Vaishali district of Bihar (India) participated in a study that identified a number of factors i.e., bonding with friends, acceptance of system, support \& cooperation, selfishness and harmony of social capital. The findings revealed that factors of social capital such as bonding with friends, acceptance of system, support \& cooperation, selfishness and harmony were significantly predicted by friendliness, emotional stability, responsibility and extraversion dimensions of personality. However, social capital factors such as selfishness and harmony were negatively predicted by the factors of personality, namely emotional stability and neuroticism.
\end{abstract}

Key words: Social Capital, Personality, Quantitative Study.

\section{Introduction}

Social capital is currently receiving a lot of attention from development agencies and research institutions and has been widely discussed across various streams of social sciences. It is a relatively new concept and has been popularized by scholars such as Bourdieu (1980), Coleman (1988); Putnam (1993); Fukuyama (1999).

Bourdieu (1986) described social capital mainly in terms of networks of relations. He defined it as "the aggregate of the actual or potential resources which are linked to possession of a durable network of more or less institutionalized relationships of mutual acquaintance and recognition- or in other words, to membership in a group". Coleman (1988) introduced social capital by outlining two broad intellectual streams in the description and explanation of social action. The first is the sociological approach, which sees the individual in a social and cultural environment subjects to norms, rules and regulations. The second is the economic approach, which is about self-interested independent individuals seeking to fulfill their goals. According to the World Bank (1999) 'Social capital refers to institutions, relationships and norms that shape 
MULTILINGUAL ACADEMIC JOURNAL OF EDUCATION AND SOCIAL SCIENCES

Vol. 5 No. 1, 2017, E-ISSN: 2308-0876 @ 2017 KWP

the quality and quantity of a society's social interaction. The central premise of social capital is that social networks have values. It refers to the collective value of all "social networks" (who people know) and the inclinations that arise from these networks to do things for each other ("norms of reciprocity")'. Furthermore, some scholars (Burt, 1998; Coleman, 1988) are of the opinion that social capital refers to resources that can be acquired through social relations.

Some people in the society find a place easily on many social networks and they have the propensity to derive benefit from societal interactions. They are perceived by people around them as more sociable, outgoing and approachable. They share their experiences with others and also show concern for others. They seem to possess high social capital. Similarly within organizations, some employees are on many formal and informal networks; they are the employees who are always "available". They keep keen interest in the affairs of the organization and interact freely with others. These persons have better networking which they leverage for their personal advancement and growth. Definitely they possess higher social capital. On the other hand, there are people both within the community and in organizations who are reserved, do not mingle freely with others and mostly keep to themselves. They are present on fewer social networks and their networking is not so strong. They seem to be lacking in their ability to profit from the societal interactions. Their social capital is low.

A pattern seems to be emerging. People's individual attitudes, values and characteristics have a bearing on their social capital. In other words individual's personality to some extent is able to predict how an individual sense, interpret and act on the information and stimuli which they receive from their environment. Therefore, personality factors can be good predictors for many aspects of social phenomena. Some personality characteristics enhance social capital; some other personality characteristics diminish social capital. The present research work was undertaken with a view to examining the predictive value of personality factors in the development of social capital. Six personality dimensions have been included in the present study, which are as follows: responsibility, emotional stability, friendliness, ego-strength, extraversion and neuroticism. Ego-strength, extraversion, friendliness, emotional stability and responsibility are those dimensions of an individual's personality that have been hypothesized to enhance social capital; while neuroticism has been hypothesized to weaken social capital. Extroverts have been found to have more social capital (Swickert, Rosentreter, Hittner \& Mushrush, 2002). Highly extroverted people are generally more warm, sociable, assertive and active (Costa \& McCrae, 1992). Based on these characteristics, it is of no surprise that extraversion is associated with the magnitude of social capital (Brown, 1996; Pollet et al. 2011).

The aim of the present study is to examine how do personality factors predict the individuals' social capital and to address the following questions:

- How do different components of social capital related to each other?

- How do personality factors such as responsibility, emotional stability, friendliness, egostrength, extraversion and neuroticism predict different components of social capital?

\section{Method of Study \\ Sample}

Sample comprised 200 students as respondents drawn from urban and rural based colleges. They were randomly selected for the present study. In terms of educational level, while $64.5 \%$ of the respondents were undergraduate, remaining $35.5 \%$ were postgraduate. The distribution of 
MULTILINGUAL ACADEMIC JOURNAL OF EDUCATION AND SOCIAL SCIENCES

Vol. 5 No. 1, 2017, E-ISSN: 2308-0876 C 2017 KWP

educational level of respondents' father was $20.5 \%$ non-matriculate, $15.0 \%$ matriculation pass, $14.0 \%$ graduate and $50.5 \%$ holding post graduate degree.

\section{Tests and Instruments}

The following tests and instruments employed:

(i) For measuring personality factors, such as responsibility, emotional stability, friendliness, and ego-strength, Differential Personality Scale (Sinha \& Singh, 1979) was used.

(ii) For measuring personality factors such as extraversion and neuroticism, a scale developed by Bhushan (1969) was used.

(iii) A set of questionnaire was developed consisting of 52 items measuring different dimensions of social capital.

(iv) A Personal Data Blank was prepared to elicit biographical and other information, such as age of the respondents, educational level, gender etc.

\section{Differential Personality Scale (Sinha \& Singh, 1976)}

In the present study, Sinha \& Singh (1976) scale was used for measuring four chosen factors of personality, namely, responsibility, emotional stability, friendliness, and ego-strength. Reliability coefficients of each of the four traits of the scale were calculated separately. For calculating reliability coefficients, test-retest and split-half methods were followed. The test-retest reliability coefficient ranged from .73 to .86 which was all statistically significant beyond .01 level of confidence. Split-half reliability of the traits was calculated by the methods; the odd-even and the first half versus second half. Split-half coefficients ranged from .82 to .90, which were all significant beyond .01 level of confidence. Inter correlations among the different dimensions were also calculated and the values of the correlations were low and statistically insignificant providing evidence for the independence of the traits. Each item in the test has two answerstrue and false. The respondent is required to read each item and decide whether the meaning of item is true or false for him or her and accordingly, encircle either 'true' or 'false'. The scoring is done with the help of the scoring-key of the instrument.

\section{Eysenck Personality Inventory (EPI)}

The Hindi version of the Eysenck Personality Inventory (Bhushan, 1969) was used to measure the personality dimensions. The inventory comprised 57 items, out of which 24 measures extraversion (E) and 24; neuroticism (N), the rest nine items constitutes the lie-scale of the inventory. The validity coefficients of the Hindi version for both extraversion $(r=.89)$ and neuroticism ( $r=.84)$ were significant. The reliability of the test was also convincingly high. For the extraversion dimension the split-half reliability ( $r i i=.64)$, test-retest reliability ( $r i i=.73$ ) and the index of reliability ( $r i i=.78$ ) were highly significant. Similarly, for the neuroticism dimension, the split-half reliability ( $r i i=.50)$, the test-retest reliability ( $r i i=.76)$ and index of reliability ( $r i i=.78$ ) were all highly significant. The reliability coefficients for the lie-scale have not been reported by the author.

\section{Development of Social Capital Measures}

Respondents' social capital was assessed with the help of the questionnaire developed by 
MULTILINGUAL ACADEMIC JOURNAL OF EDUCATION AND SOCIAL SCIENCES

Vol. 5 No. 1, 2017, E-ISSN: 2308-0876 @ 2017 KWP

Lakshmi (2015). The responses were rated on a 5-points scale ranging from 'strongly agree' to 'strongly disagree'. Initially, the questionnaire comprised of 60 items to assess the social capital of the respondents. Subsequently, eight items were dropped on the basis of item analysis. Finally, responses to the remaining 52 items were factor analyzed using the principal component analysis (PCA) with rotated varimax solution on the criteria that eigenvalue should not be less than 1 (one) and the factor must have acceptable reliability (alpha coefficient $>.60$ ). An initial analysis (SPSS17 version) was run to obtain eigenvalue for each factor of the data. Kaiser's (1960) rule was followed to determine which factors were more eligible for interpretation because this rule requires that a given factor is capable of explaining at least the equivalent of one variable's variance. Using this rule, five factors had eigenvalue over Kaiser's criterion of 1 . This criterion is based on the idea that the eigenvalue represents the amount of variation explained by a factor.

Fourteen items were eliminated because they did not contribute to a simple factor structure and failed to meet a minimum criteria of having factor loading of .40 or above. Two items namely, 'family members keep their own interest even in collective work', and 'family members feel jealous of each other's successes' have been reversed in the final analysis of factor analysis as they have negative loading. The purpose of reverse scoring is to prevent a cancelling out of variables with positive and negative loadings. The rationale behind selection of factor loading of .40 and above is the sample size comprising 200 respondents. The summary of exploratory factor analysis results along with high loading items, mean, standard deviation and variance explained by the factors has been presented in Table 1.

Table 1.Exploratory Factor Analysis Results for Social Capital Questionnaire

\begin{tabular}{|l|l|l|l|l|}
\hline \multicolumn{3}{|l}{ Factor $\mathbf{1}$ Bonding with Friends (N=13, $\mathbf{M = 4 2 . 8 0 , ~ S D = 8 . 8 4 , ~ r i i = . 8 0 , ~ V = 7 8 . 2 0 , ~ E i g e n v a l u e = ~ 1 2 . 5 6 ) ~}$} \\
\hline $\mathbf{S ~ N}$ & Items & Loading & Mean & SD \\
\hline $\mathbf{3 9}$ & You understand problems of your friends as your own. & .66 & 3.67 & 1.17 \\
\hline $\mathbf{3 6}$ & $\begin{array}{l}\text { You are aware of the problems of your friends even without } \\
\text { any hint. }\end{array}$ & .58 & 2.90 & 1.21 \\
\hline $\mathbf{0 7}$ & You are always ready to help your friends. & .58 & 4.20 & .89 \\
\hline $\mathbf{0 8}$ & Will your friends help you at the time of crisis? & .55 & 3.26 & 1.29 \\
\hline $\mathbf{0 1}$ & You trust your friends. & .53 & 3.12 & 1.28 \\
\hline $\mathbf{4 0}$ & You talk freely with your friends. & .53 & 3.85 & 1.24 \\
\hline $\mathbf{0 4}$ & Your friends are ready to help you when you need them. & .52 & 3.33 & 1.28 \\
\hline $\mathbf{0 3}$ & You make friends easily. & .49 & 2.71 & 1.53 \\
\hline $\mathbf{1 1}$ & All friends come together at the time of crisis. & .45 & 3.74 & 1.38 \\
\hline $\mathbf{4 3}$ & $\begin{array}{l}\text { You solve your problems yourself without taking anybody's } \\
\text { help. }\end{array}$ & .45 & 2.98 & 1.22 \\
\hline $\mathbf{5 1}$ & $\begin{array}{l}\text { You do agree with your friends suppressing your own } \\
\text { desires. }\end{array}$ & .44 & 2.44 & 1.16 \\
\hline $\mathbf{0 5}$ & You go by your friends' advice. & .42 & 3.15 & 1.09 \\
\hline $\mathbf{3 8}$ & You resolve any differences with your friends easily. & .42 & 3.48 & 1.34 \\
\hline Factor $\mathbf{2}$ Acceptance of System (N=6, M=15.67, SD=4.94, rii=-.73, V=24.36, Eigenvalue=6.47) \\
\hline $\mathbf{2 7}$ & $\begin{array}{l}\text { You have trust in the law \& order situation of the } \\
\text { government. }\end{array}$ & .79 & $\mathbf{2 . 9 1}$ & 1.27 \\
\hline
\end{tabular}


MULTILINGUAL ACADEMIC JOURNAL OF EDUCATION AND SOCIAL SCIENCES

Vol. 5 No. 1, 2017, E-ISSN: 2308-0876 @ 2017 KWP

\begin{tabular}{|c|c|c|c|c|}
\hline 49 & Do you have trust in government schemes? & .70 & 2.72 & 1.15 \\
\hline 50 & Law \& order situation of government is satisfactory. & .67 & 2.65 & 1.15 \\
\hline 26 & You are satisfied with your government policies. & .67 & 2.71 & 1.22 \\
\hline 47 & People do their work efficiently in government offices. & .57 & 2.41 & 1.34 \\
\hline 28 & $\begin{array}{l}\text { You feel satisfied with the condition of government } \\
\text { hospitals. }\end{array}$ & .45 & 2.28 & 1.26 \\
\hline \multicolumn{5}{|c|}{ Factor 3 Support \& Cooperation $(N=9, M=24.75, S D=5.89$, rii $=.72, V=34.64$, Eigenvalue $=5.84$} \\
\hline 16 & You know what your neighbors are doing in their daily lives. & .58 & 1.94 & 1.12 \\
\hline 18 & Your neighbors fully participate in social activities. & .52 & 2.97 & 1.36 \\
\hline 35 & You like to spend time with your neighbors. & .50 & 2.31 & 1.13 \\
\hline 45 & You listen to the advice of your neighbours. & .49 & 2.70 & 1.11 \\
\hline 19 & Your neighbours trust you. & .48 & 3.29 & 1.67 \\
\hline 23 & You like to get help from your neighbours again and again. & .44 & 1.67 & 0.94 \\
\hline 21 & Your neighbours are ready to help you. & .44 & 3.21 & 1.22 \\
\hline 15 & How close are you with your neighbours? & .43 & 3.18 & 1.29 \\
\hline 20 & Your neighbours actively participate in religious activities. & .42 & 3.52 & 1.24 \\
\hline \multicolumn{5}{|c|}{ Factor 4 Selfishness (N=4, M=11.75, SD=3.60, rii=.60, V=12.93, Eigenvalue=5.03) } \\
\hline 2 & $\begin{array}{l}\text { Most of your friends are busy with their own selfish } \\
\text { behavior. }\end{array}$ & .70 & 2.71 & 1.44 \\
\hline 12 & Your friends are jealous of your success. & .63 & 2.27 & 1.29 \\
\hline 17 & Your neighbors simply take advantage of you. & .50 & 2.90 & 1.46 \\
\hline 46 & People see their own interests in government activities. & .47 & 3.88 & 1.88 \\
\hline \multicolumn{5}{|c|}{ Factor 5 - Harmony ( $\mathrm{N}=6, \mathrm{M}=26.01, \mathrm{SD}=3.81$, rii=.68, $\mathrm{V}=14.50$, Eigenvalue 3.99) } \\
\hline 31 & Family members become united at the time of crisis. & .68 & 4.64 & .82 \\
\hline 29 & There is brotherhood in our family & .64 & 4.34 & 1.02 \\
\hline 30 & Do you feel proud of your family? & .62 & 4.59 & .80 \\
\hline 42 & $\begin{array}{l}\text { Family members keep their own interest even in collective } \\
\text { work. }\end{array}$ & -.51 & 3.84 & 1.35 \\
\hline 32 & Family members feel jealous of each other's success. & -.51 & 4.04 & 1.36 \\
\hline 14 & You obey order of elders in your family. & .46 & 4.58 & .73 \\
\hline
\end{tabular}

Table 1 reports the factor loadings after rotation and five factors were extracted. The varimax rotation method was then used to perform orthogonal rotation to eliminate items with factor loading <.40. It is also clear from Table 1 that thirteen items such as 'you understand the problems of your friends as your own', 'you are aware of the problems of your friends even without any hint', you are always ready to help your friends', 'will your friends help you at the time of crisis', 'you trust your friends', 'you talk freely with your friends', 'your friends are ready to help you when you need them', 'you make friends easily', 'all friends come together at the time of crisis', 'you solve your own problem without anybody's help', 'you do agree with your friends suppressing your own desires', 'you go by your friends' advice', 'you resolve any differences with your friends easily' were loaded on Factor I which was given the name, 'Bonding with friends'. The factor explained 78.20 per cent of the common variance and also showed 
MULTILINGUAL ACADEMIC JOURNAL OF EDUCATION AND SOCIAL SCIENCES

Vol. 5 No. 1, 2017, E-ISSN: 2308-0876 @ 2017 KWP

higher reliability ( $r i i=.80)$.

The items such as 'you have trust in the law \& order situation of the government,' 'do you have trust in government schemes,' 'law \& order situation of government is satisfactory,' 'you are satisfied with your government policies,' 'people do their work efficiently in government offices,' 'you feel satisfied with the condition of government hospitals' were loaded on Factor II which was given the name, 'Acceptance of system. The factor explained 24.36 per cent of the common variance and also showed higher reliability ( $r i i=.73$ ).

The items such as, 'you know what your neighbours are doing in their daily lives,' 'your neighbour's fully participation in social activities,' 'you like to spend time with your neighbours,' 'you listen to the advice of your neighbours', 'your neighbors trust you,' 'you like to get help from your neighbours again and again,' 'your neighbors are ready to help you,' 'how close are you with your neighbours,' 'your neighbour actively participate in religious activities' were loaded on Factor III which was given the name, 'Support and cooperation'. This factor explained 34.64 per cent of the common variance and also showed higher reliability ( $r i i=.72$ ).

The four items such as, 'most of your friends are busy with their own selfish behaviour', 'your friends are jealous of your success', 'your neighbours simply take advantage of you', 'people see their own interest in government activities' were loaded on Factor IV which was given the name, 'Selfishness'. This factor explained 12.93 per cent of the common variance and also showed higher reliability ( $r i i=.60)$.

The six items such as, 'family members get united at the time of crisis', 'there is brotherhood in your family', 'do you feel proud of your family', 'family members keep their own interest even in collective work', 'family members feel jealous of each other's success', 'you obey your elders in your family' were loaded on Factor $V$ which was given the name, 'Harmony'. This factor explained 14.50 per cent of the common variance and also showed higher reliability ( $r i i=$ .68).

\section{Results}

In order to examine the pattern of relationship among the different factors of social capital, coefficients of correlation have been computed. Table 2 presents the summary of the coefficients of correlation.

Table 2.Mean, SD \& Inter-correlations of Factors of Social Capital

\begin{tabular}{|l|c|c|c|c|}
\hline Factors & 1 & 2 & 3 & 4 \\
\hline 1.Bonding with friends & & & & \\
\hline 2.Acceptance of system & .11 & & & \\
\hline 3.Support \& Cooperation & $.37^{* *}$ & $.27^{* *}$ & & \\
\hline 4.Selfisness & $-.26^{* *}$ & -.13 & $-.22^{* *}$ & \\
\hline 5.Harmony & $.17^{*}$ & .02 & $.20^{* *}$ & $-.21^{* *}$ \\
\hline \multicolumn{2}{|c|}{${ }^{* * p<.01,{ }^{*} p<.05, \mathrm{~N}=200}$} & & & \\
\hline
\end{tabular}

It is clear from Table 2 that the factor of social capital such as bonding with friendsis 
MULTILINGUAL ACADEMIC JOURNAL OF EDUCATION AND SOCIAL SCIENCES

Vol. 5 No. 1, 2017, E-ISSN: 2308-0876 @ 2017 KWP

positively associated to support \& cooperation $(r=.30, p<.01)$ and harmony $(r=.17, p<.01)$; whereas negatively related to selfishness $(r=-.26, p<.01)$. Acceptanceofsystemis also positively correlated to support \& cooperation $(r=.27, p<.05)$. However, support \& cooperation is negatively related to selfishness( $r=-.22, p<.05)$. Selfishness is negatively associated to harmony $(r=.-21, P<.05)$. The findings are partially in the hypothesized direction in the case of the social capital factors i.e. bonding with friends, support \& cooperation, and harmony.

As the purpose of the study is to find out the relative contributions of personality factors (e.g., extraversion, neuroticism, responsibility, emotional stability, friendliness and ego-strength) considered as predictors and factors of social capital (e.g., bonding with friends, acceptance of system, support \&cooperation, selfishness and harmony) as criterion variables, multiple stepwise regression analysis has been performed to evaluate whether factors of personality scores are necessary to predict factors of social capital. Table 3 presents the summary of stepwise regression analysis.

Table 3. Stepwise Regression Analysis of Social Capital Factor (Bonding with Friends) Predicted by the Personality Factors

\begin{tabular}{|c|c|c|c|c|c|c|}
\hline Factors & $\mathbf{R}$ & R Square & $\begin{array}{ll}\text { Adjusted } & R \\
\text { Square } & \\
\end{array}$ & Std. Beta & $\mathbf{F}$ & df \\
\hline Friendliness & .33 & .11 & .11 & .33 & $24.34 * *$ & $1 / 198$ \\
\hline Emotional Stability & .37 & .14 & .13 & .17 & $15.73 * *$ & $2 / 197$ \\
\hline Extraversion & .41 & .16 & .15 & .16 & $12.84^{* *}$ & $3 / 196$ \\
\hline
\end{tabular}

Table 3 shows that all three $F$ - tests provide the results of a test of significance for $\mathrm{R}$ square, such as friendliness $F(1,198)=24.34, p<.01$, emotional stability $F(2,197)=15.73, p<.01$, and extraversion $F(3,196)=12.84, p<.01$ are statistically significant indicating that the relationships are linear. Therefore, the model significantly predicts the criterion variable i.e. bonding with friends. The value of $\mathrm{R}$-square $\left(\mathrm{R}^{2}=11\right)$ for friendliness indicates thatthe amount of variance in the criterion variable, bonding with friends by the predictor variable, friendliness. In this case, the friendliness, emotional stability and extraversion 11, 14 and 16 per cent of the variance accounted for by bonding with friends.

Adjusted R-square $\left(R^{2}\right)$ adjusts the value of $R^{2}$ when the sample size is small. The rule of thumb is to report adjusted $R^{2}$ when it substantially differs from $R^{2}$ (Green \& Salkind, 2010). In this analysis, the value of $R^{2}$ and the adjusted $R^{2}$ are slightly different. However, the review of the standardized regression coefficient Beta $(\beta)$ value for friendliness $(\beta=.33)$ has positively associated to factor i.e. bonding with friends whereas emotional stability $(B=.17)$ and extraversion $(b=.16)$ were statistically significant. On the basis of the obtained results, it can be concluded that the social capital factor, bonding with friends was primarily predicted to friendliness factor of personality followed by emotional stability and extraversion. Other personality factors, such as ego-strength, responsibility and neuroticism did not contribute significantly to bonding with friends component of social capital.

Again a stepwise multiple regression analysis has been performed to evaluate whether 
MULTILINGUAL ACADEMIC JOURNAL OF EDUCATION AND SOCIAL SCIENCES

Vol. 5 No. 1, 2017, E-ISSN: 2308-0876 @ 2017 KWP

factors of personality scores are necessary to predict factor of social capital such as acceptance of system. Table 4 present the summary of regression analysis.

Table 4 Stepwise Regression Analysis of Social Capital Factor (Acceptance of System) Predicted by the Personality Factors

\begin{tabular}{|c|c|c|c|c|c|c|}
\hline Factors & $\mathbf{R}$ & R Square & $\begin{array}{ll}\text { Adjusted } & \mathbf{R} \\
\text { Square } & \\
\end{array}$ & Std. Beta & $\mathbf{F}$ & df \\
\hline $\begin{array}{l}\text { Emotional } \\
\text { Stability }\end{array}$ & .24 & .06 & .05 & .24 & $11.93 * *$ & $1 / 198$ \\
\hline Responsibility & .28 & .08 & .07 & .15 & $8.59 * *$ & $2 / 197$ \\
\hline
\end{tabular}

${ }^{*} \mathrm{p}<.05,{ }^{* *} \mathrm{p}<.01, \mathrm{~N}=200$

Table 4 shows that the two factors $F$-test provides the results of a test of significance for R-square such as emotional stability $F(1,198)=11.93, p<.01$ and responsibility $F(2,197)=8.59$, $p<.05$ are statistically significant indicating that the relationships are linear. Therefore, the model significantly predicts the criterion variables, acceptance of system. The value of $R$-square $\left(R^{2}=.06\right)$ for emotional stability indicates that the amount of variance in the criterion variable, acceptance of system by the predictor variable such as emotional stability. In this case, the emotional stability, responsibility 6 and 8 per cent of the variance accounted for by acceptance of system. However, the review of the standardized regression coefficient Beta $(\beta)$ value for emotional stability $(B=.24)$ has been positively associated to acceptance of system component of social capital whereas, responsibility $(\beta=.15)$ were statistically significant. It may be concluded that acceptance of system, one of the components of social capital was substantially predicted to personality factors, emotional stability and responsibility.

It is of interest to evaluate whether factors of personality scores are necessary to predict the factor of social capital dimension such as support \& cooperation, a stepwise multiple regression analysis has been performed. Table 5 present the summary of regression analysis.

Table 5 Stepwise Regression Analysis of Social Capital Factor (Support \& Cooperation) Predicted by the Personality Factors

\begin{tabular}{|l|l|l|l|l|l|l|}
\hline Factors & $\mathbf{R}$ & $\mathbf{R}^{\mathbf{2}}$ & Adjusted R & Std. Beta & $\mathbf{F}$ & $\mathbf{d f}$ \\
\hline Friendliness & .26 & .07 & .06 & .26 & 14.62 & $1 / 198$ \\
\hline Responsibility & .30 & .09 & .08 & .15 & 9.88 & $2 / 197$ \\
\hline
\end{tabular}

Table 5 shows that the two factors $F$-test provides the results of a test of significance for R-square such as friendliness $F(1,198)=14.62, p<.01$ and responsibility $F(2,197)=9.88, p<.05$ are statistically significant indicating that the relationships are linear. Therefore, the model significantly predicts the criterion variables, support \& cooperation. The value of R-square $\left(\mathrm{R}^{2}=.07\right)$ for friendliness indicates that the amount of variance in the criterion variable such as support \& cooperation by the predictor variable, friendliness. In this case, the friendliness, responsibility 7 and 9 per cent of the variance accounted for by support \& cooperation. However, the review of the standardized regression coefficient Beta $(\beta)$ value for friendliness $(\beta=.26)$ has 
MULTILINGUAL ACADEMIC JOURNAL OF EDUCATION AND SOCIAL SCIENCES

Vol. 5 No. 1, 2017, E-ISSN: 2308-0876 @ 2017 KWP

been positively associated to support \& cooperation component of social capital whereas, responsibility $(b=.15)$ are statistically significant. On the basis of results, it may be concluded that support and cooperation component of social capital was chiefly predicted to friendliness dimension of personality.

A stepwise multiple regression analysis has been performed to evaluate whether factors of personality scores are necessary to predict factors of social capital such asselfishness. Table 6 presents the summary of regression analysis.

Table 6. Stepwise Regression Analysis of Social Capital Factor (Selfishness) Predicted by the Personality Factors

\begin{tabular}{|l|l|l|l|l|l|l|}
\hline Factors & R & $\mathbf{R}^{\mathbf{2}}$ & AdjustedR $^{2}$ & Std. Beta & F & df \\
\hline Neuroticism & .24 & .06 & .05 & .24 & 11.78 & $1 / 198$ \\
\hline $\begin{array}{l}\text { Emotional } \\
\text { Stability }\end{array}$ & .28 & .08 & .07 & -.15 & 8.17 & $2 / 197$ \\
\hline
\end{tabular}

Table 6 shows that the two factors $F$ - tests provides the results of a test of significance for R-square such as neuroticism $F(1,198)=11.78, p<.01$, and emotional stability $F(2,197)=8.17$, $p<05$ are statistically significantly indicating that the relationships are linear. Therefore, the model significantly predicts the criterion variable, selfishness. The value of $R$-square $\left(R^{2}=.06\right)$ for neuroticism indicates that the amount of variance in the criterion variable i.e. selfishness by the predictor variable such as neuroticism. In this case, the neuroticism and emotional stability 5 and 7 per cent of the variance accounted for by selfishness. However, the review of the standardized regression coefficient Beta $(\beta)$ value for neuroticism $(\beta=.24)$ has been positively associated to selfishness component of social capital whereas, emotional stability $(B=-.15)$ has negatively associated to selfishness, are statistically significant. Finally, it can be concluded that selfishness as the component of social capital was greatly predicted to neuroticism dimension of personality; whereas negatively predicted to emotion stability.

A stepwise multiple regression analysis has been performed to evaluate whether factors of personality scores are necessary to predict factors of social capital such as harmony. Table 7 presents the summary of regression analysis.

Table 7. Stepwise Regression Analysis of Social Capital Factor (Harmony) Predicted by the Personality Factors

\begin{tabular}{|c|c|c|c|c|c|c|}
\hline Factors & $\mathbf{R}$ & $\mathbf{R}^{2}$ & AdjustedR ${ }^{2}$ & Std. Beta & $\mathbf{F}$ & df \\
\hline Neuroticism & .27 & .07 & .07 & -.27 & 15.25 & $1 / 198$ \\
\hline Emotional Stability & .32 & .10 & .10 & .19 & 11.39 & $2 / 197$ \\
\hline
\end{tabular}

${ }^{*} p<.05,{ }^{* *} p<.01, N=200$

Table 7 shows that the two factors F-tests provides the results of a test of significance for R-square such as neuroticism $F(1,198)=15.25, p<.01$ and emotional stability $F(2,197)=11.39$, $p<.01$ are statistically significant indicating that the relationships are linear. Therefore, the model significantly predicts the criterion variable i.e. harmony. The value of R-square $\left(R^{2}=.07\right)$ for neuroticism indicates that the amount of variance in the criterion variable, harmony by the 
MULTILINGUAL ACADEMIC JOURNAL OF EDUCATION AND SOCIAL SCIENCES

Vol. 5 No. 1, 2017, E-ISSN: 2308-0876 @ 2017 KWP

predictor variable, neuroticism. The neuroticism and emotional stability 7 and 10 per cent of the variance accounted for by harmony. However, the review of the standardized regression coefficient Beta $(\beta)$ value for neuroticism $(B=-.27)$ has been negatively associated to harmony of social capital whereas, emotional stability $(B=-19)$ has positively associated to harmony, are statistically significant. It may be concluded that harmony component of social capital was chiefly predicted to emotional stability dimension of personality; whereas negatively predicted to neuroticism.

\section{Discussion}

The aim of the study was to examine the pattern of relationship among the factors of social capital and also relative significant predictive values of personality factors for the different factors of social capital. Friendliness among the personality factors was the best predictor of social capital factor such as Bonding with friends followed by emotional stability and extraversion. The finding was also in congruence with the finding of Sheldon (2008) who suggested that extroverted individuals benefit from social network sites more than introverted individuals. Some previous studies (Russel et al. 1997; Anderson et al. 2001) reported that extroverted individuals have been found to have larger networks and higher contact frequencies. However, a more recent study by Grant (2013) showed that higher levels of extraversion are not necessarily beneficial. Moderately extraverted salespeople have better sales revenues than lowly or highly extraverted salespeople.

Emotional stability was the chief predictor of social capital factor acceptance of system followed by responsibility dimension of personality. Costa and McCrae (1992) suggested that emotionally stable individuals showed fewer negative emotions like anxiety, stress and negative effect. So that emotionally stable individuals are likely to have more extensive networks and better capable of adapting to interpersonal differences (Klien et al. 2004).

Friendliness was the best predictor of social capital factor support \& cooperation followed by responsibility dimension of personality. Neuroticism was the main predictor of social capital factor selfishness followed by emotional stability. Neuroticism is generally assumed to be negatively associated with social relationship (Wanberg et al. 2000). Neuroticism was the best predictor of absence of social capital factor harmony as the standardized regression coefficient Beta $(\beta)$ value for neuroticism had been negatively associated to harmony. However, emotional stability had positively associated to harmony were statistically significant.

In general, the study shows that extraversion, emotional stability, responsibility and friendliness factors of personality play an important role in predicting the components of social capital. In addition, there are several considerations that need to be taken into account when considering the findings of the current study. First, the study is primarily based on self-report data. As a result, the strength of relations between variable was overestimated due to common method of variance. Second, the nature and forms of social capital change over time as well as the multidimensional construct of both personality and social capital.

\section{References}

Anderson, C., John, O. P., Keltner, D., \& Kring, A. M. (2001). Who Attains Social Status? Effects of Personality and Physical Attractiveness in Three Social Groups. Journal of Personality and Social Psychology 81, 116-132. 
MULTILINGUAL ACADEMIC JOURNAL OF EDUCATION AND SOCIAL SCIENCES

Vol. 5 No. 1, 2017, E-ISSN: 2308-0876 @ 2017 KWP

Bhushan, L. I. (1969). A Hindi Version of Eysenck Personality Inventory (Form a), Psychology Annual, 3, 27-30.

Bourdieu, P. (1980). Le capital social: notes provisoires, in: Actes de la Recherche en Sciences Sociales, Vol. 31, 2-3.

Bourdieu, P. (1986). The forms of capital. In J. Richardson (Ed.) Handbook of Theory and Researchfor the Sociology of Education (New York, Greenwood), 241-258.

Brown, S. P. (1996). A meta-analysis and review of organizational research on job involvement. Psychological Bulletin, 120, 235-255.

Burt, R. S. (1998). The gender of social capital. Rationality and Society, 10, 105-46.

Coleman, J. S. (1988). 'Social Capital in the Creation of Human Capital.' The American Journal of Sociology 94: S95.

Costa, P. T., Jr., \& McCrae, R. R. (1992). Reply to Ben-Porath and Waller. Psychological Assessment, 4, 20-22

Fukuyama, F. (1995). Social capital and the global economy. Foreign Affairs, 74, 89-103.

Fukuyama, F. (1999). Social capital and civic society. Paper Presented at the IMF Conference on Second Generation Reforms, IMF Headquarters Washington, DC.

Grant, A. M. (2013). Rethinking the extraverted sales ideal: the Ambivert advantage. Psychological Science, 24, 1024-1030.

Green, S. B., \& Salkind, N. J. (2010). Using SPSS for Windows and Macintosh:Analyzing and understanding data ( $6^{\text {th }} E d$.). Upper Saddle River, NJ: Prentice Hall.

Kaiser, H. F. (1958). The variance criterion for analytic rotation in factor analysis. Psychometrika, 23, 182-200.

Klein, K. J., Lim, B., Saltz, J. L., \& Mayer, D. M. (2004). How do they get there? An examination of the antecedents of centrality in team networks. The Academy of Management Journal, 46, 952-963.

Lakshmi, S. (2015). Personality Correlates of Social Capital. Unpublished Ph. D. Thesis, B R A Bihar University, Muzaffarpur (Bihar).

Pollet, T. V., Roberts, S. G. B., \& Dunbar, R. I. M. (2011). Extroverts have larger networks layers: but do not feel emotionally closer to individuals at any layer. Journal of Individual Differences, 32, 161-169.

Putnam, R. D. (1993). "The prosperous community: Social capital and public life". The American Prospect 4.

Putnam, R. D. (2000). Bowling alone: the collapse and revival of American community. New York: Simon \& Schuster.

Russel, D. W., Booth, B., Reed, D., \& Laughlin, P. R. (1997). Personality, Social Networks, and Perceived Social Support among Alcoholics: A Structural Equation Analysis. Journal of Personality, 63(3), 649-692.

Sheldon, P. (2008). The relationship between unwillingness-to-communicate and students'Facebook use. Journal of Media Psychology: Theories, Methods, and Applications 20(2): 65-75.

Sinha, L. N. K., \& Singh, A. K. (1976). Development of Differential PersonalityScalein Hindi.Unpublished Ph.D. Thesis, Patna University, Patna

Swickert, R. J., Rosentreter, C. J., Hittner, J. B., \& Mushrush, J. E. (2002). Extraversion,social support processes and stress. Personality and Individual Differences, 32, 877-891. 
MULTILINGUAL ACADEMIC JOURNAL OF EDUCATION AND SOCIAL SCIENCES

Vol. 5 No. 1, 2017, E-ISSN: 2308-0876 @ 2017 KWP

Wanberg, C. R., Kanfer, R., \& Banas, J. T. (2000). Predictors and Outcomes of Networking Intensity among Unemployed Job seekers. Journal of Applied Psychology, 85, 491-503.

World Bank. (1999). 'What is social capital?'

PovertyNethttp://www.worldbank.org/poverty/scapital/ whatsc.htm

\section{Bionotes}

Dr S. Lakshmi is Research scholar, PG Dept. of Psychology, BRA Bihar University, Muzaffarpur. E-mail: lakshmi.swarupa1203@gmail.com

Prof. R. Lakshmi is Associate Professor, Dept. of Psychology, RN College, Hajipur E-mail: rupalakshmi29@gmail.com

Prof. R. B. N. Sinha is Professor of Psychology \& Coordinator of MBA, BS College, Danapur, Patna 800 012,

E-mail: rbns2@rediffmail.com 